\title{
Two New Norphenylpropanoid Glucosides and Hemipholin from the Flowers of Ononis vaginalis
}

\author{
Maged S. Abdel-Kader \\ Department of Chemistry, Virginia Polytechnic Institute and State University, \\ Blacksburg, Virginia 24061-0212, USA.
}

Received: May 12, 1997

\begin{abstract}
Do extrato butanólico das flores de Ononis vaginalis Vahl. Symb. foram isolados dois novos glicosídeos norfenilpropanóides: $1 \beta$-D-glicopiranosil-2-(4'hidroxifenil) (E)-eteno (trans-vaginosídeo) e $1 \beta$-D-glicopiranosil-2-(4'hidroxifenil) (Z)-eteno (cis-vaginosídeo), e a flavanona C-glicosilada (+) 6-C- $\beta$-D-glicopiranosil ( $2 S$ ) naringenina (hemifolina). As estruturas destes compostos foram determinadas por métodos químicos e espectroscópicos.
\end{abstract}

The butanol extract of the flowers of Ononis vaginalis Vahl. Symb. afforded two new norphenylpropanoid glucosides, 1- $\beta$-D-glucopyranosyl-2-(4'-hydroxyphenyl) (E)-ethene (transvaginoside), 1- $\beta$-D-glucopyranosyl-2-(4'-hydroxyphenyl) ( $Z$ )-ethene (cis-vaginoside) as well as the known flavanone C-glucoside, (+)-6-C- $\beta$-D-glucopyranosyl $(2 S)$ naringenin (hemipholin). The structures of the isolated compounds were established utilizing chemical and spectroscopic methods. coside

Keywords: Ononis vaginalis, fabaceae, norphenylpropanoid glucosides, flavanone $C$-glu-

\section{Introduction}

The genus Ononis (Fabaceae) is represented in Egypt by eight species ${ }^{1,2}$. Several plants belonging to the genus are known to be used in the treatment of jaundice, urinary tract inflammations and kidney stones ${ }^{3}$. Recently, a number of alkyl resorcinols were isolated from Ononis species ${ }^{4}$. This class of naturally occurring compounds are glycerol3-phosphate dehydrogenase inhibitors ${ }^{5}$ and cleave DNA through selective strand scission ${ }^{6}$. Previous investigation of the non polar ether fractions of the flowers of Ononis vaginalis resulted in the isolation of seven flavonoids ${ }^{7}$. Among these, eupatilin is known to have a cytotoxic action against human carcinoma of nasopharynx ${ }^{8}$ and trifolin proved to have an insect growth regulator like action 9 . However, the more polar butanol fraction was not subjected to more detailed investigation.

\section{Results and Discussions}

Compound 1 was isolated in the form of a yellowish gum. The UV $\lambda_{\max }$ absorption at $263 \mathrm{~nm}$ indicated its aromatic nature. In the ${ }^{1} \mathrm{H}-\mathrm{NMR}$ of $\mathbf{1}$ (Table 1 ), the two

Permanent address: Department of Pharmacognosy, College of Pharmacy, University of Alexandria, Alexandria, Egypt. doublets at 7.08 and $7.46 \mathrm{ppm}(J=8.4 \mathrm{~Hz}, 2 \mathrm{H}$ each $)$ as well as their correlated carbons (base on a HETCOR experiment) at 117.7 and 130.4 ppm respectively, (see experimental) were diagnostic for a $p$-substituted benzene ring. Another two doublets at $6.39,7.37 \mathrm{ppm}(J=16 \mathrm{~Hz}, 1 \mathrm{H}$ each) and their correlated carbons at 131.0 and $141.9 \mathrm{ppm}$ were assigned for conjugated methines with their protons having the trans- orientation ${ }^{10}$. The chemical shifts of the carbons equivalent to $\mathrm{C}-1$ in cinnamic acid and its derivatives is usually around $115 \mathrm{ppm}^{11}$, while the $141.9 \mathrm{ppm}$ resonance in $\mathbf{1}$ indicates that $\mathrm{C}-1$ is oxygenated. The quaternary carbon resonances at 136.1 and 158.5 ppm were in complete agreement with carbon and oxygen substitutions on the aromatic system. Both ${ }^{1} \mathrm{H}$ - and ${ }^{13} \mathrm{C}-\mathrm{NMR}$ showed signals diagnostic for $\beta$-D-glucopyranoside. FABMS showed an $\left[\mathrm{M}^{+}+\mathrm{H}\right]$ at $299 \mathrm{~m} / \mathrm{z}(100 \%)$ consistent with the molecular formula $\mathrm{C}_{14} \mathrm{H}_{18} \mathrm{O}_{7}$ as indicated from ${ }^{1} \mathrm{H},{ }^{13} \mathrm{C}$ $\mathrm{NMR}$ and DEPT experiments. Positive reaction to $\mathrm{FeCl}_{3}$, $12 \mathrm{~nm}$ UV bathochromic shift after the addition of $\mathrm{NaOMe}$ and the instability of the enol form (if the sugar part was attached to the phenolic $\mathrm{OH}$ ) all support the position of glucose to be at C-1. Acid hydrolysis of 1 generated $\beta$-D- 
<smiles>[R]C=C[2H]</smiles>

1
2<smiles>[R]C=C[R]</smiles>

$\mathbf{R}=\beta$-D-glucopyranosyul<smiles>[R]=Cc1ccc(C)cc1</smiles>

glucose (identified by TLC comparison with authentic material) and an aglycone identified as (4-hydroxyphenyl)-acetaldehyde through comparing its ${ }^{1} \mathrm{H}-\mathrm{NMR}$ data with those in the literature ${ }^{12}$. As in cyanogentic glycosides; the glycosidic linkage is the main stabilizing factor for the aglycone. Consequently, hydrolysis of $\mathbf{1}$ resulted in the formation of the stable (4-hydroxy-phenyl)-acetaldehyde (keto form) rather than the unstable enol form.

Compound 2 showed essentially similar spectral characteristics to those of $\mathbf{1}$ (Table 1 and experimental). The major significant differences are in the $J_{1,2}$ value $(16 \mathrm{~Hz}$ in 1 and $12 \mathrm{~Hz}$ in 2) as well as H-1 and H-2 chemical shift (6.39, $7.37 \mathrm{ppm}$ in $\mathbf{1}$ and 5.94, $6.33 \mathrm{ppm}$ in $\mathbf{2}$ ) indicating that $\mathbf{2}$ is the cis-isomer of $\mathbf{1}^{10}$.

Compound 3 was identified as hemipholin (6-C- $\beta-D-$ glucopyranosyl ( $2 S$ ) naringenin) through comparison of its data (see experimental) with those in the literature ${ }^{13,14}$ as well as its positive reaction with Gibb's reagent eliminating the possibility of the sugar to be attached to $\mathrm{C}-8^{15}$. The assignment of the unreported ${ }^{13} \mathrm{C}-\mathrm{NMR}$ data for $\mathbf{3}$ were<smiles>O=C1C[C@@H](c2ccc(O)cc2)Oc2cc(O)c(Cl)c(O)c21</smiles>

performed based on HETCOR experiments as well as comparison with the data of 6,8 -di-C- $\beta$-D-glucopyranosyl (2S) naringenin ${ }^{16}$.

\section{Experimental}

\section{General procedure}

The melting point was determined using a Griffin melting point apparatus and was uncorrected. UV spectra were obtained in $\mathrm{MeOH}$ on a Pye Unicam Sp8-100 spectrometer. CD spectrum was recorded using a Jasco J-720 spectropolarimeter. NMR spectra were measured with a Bruker Ac-300 spectrometer at 300 and $75 \mathrm{MHz}$ for ${ }^{1} \mathrm{H}$ - and ${ }^{13} \mathrm{C}$-NMR respectively. Proton and carbon chemical shifts are reported in parts per million (ppm) relative to residual undeuterated solvent. The carbon chemical shifts for $\mathbf{1}$ in $\mathrm{D}_{2} \mathrm{O}$ are reported relative to C- 6 of glucose at $61.5 \mathrm{ppm}$. $\mathrm{FAB}$ and Electrospray mass spectra were recorded using a Quattro-SQ mass spectrometer. $\beta$-D-Glucose was obtained from Sigma Chemical Co.

\section{Plant material}

Plant materials of Ononis vaginalis Vahl. Symb. (voucher MSA2) described earlier ${ }^{7}$ were collected on April 5, 1995 from El Agamy, Alexandria, Egypt.

\section{Extraction and isolation}

$1.5 \mathrm{~kg}$ of fresh flowers of Ononis vaginalis were extracted with $95 \%$ ethanol $(10 \mathrm{~L})$. The concentrated ethanolic extract $(150 \mathrm{~mL})$ was diluted with $300 \mathrm{~mL}$ water and successively extracted with light petrol $(3 \times 500 \mathrm{~mL})$, ether $(3 \times 500 \mathrm{~mL})$, ethyl acetate $(3 \times 300 \mathrm{~mL})$ and butanol $(2 \times$ $300 \mathrm{~mL}$ ).

The dried butanol fraction $(7 \mathrm{~g})$ was fractionated by VLC over silica gel $(400 \mathrm{~g})$ using fritted funnel $(10 \times 8.5$ $\mathrm{cm}$ ) and eluted with EtOAc/ MeOH mixtures. Fractions 10-12 (0.5 g), eluted with $10 \% \mathrm{MeOH}$ in EtOAc, were refractionated over a flash column $(2 \mathrm{~cm}$ in diameter, $25 \mathrm{~g}$ silica gel) eluted with $10 \% \mathrm{MeOH}$ in $\mathrm{CHCl}_{3}$. Fractions 4-7

Table 1. ${ }^{1} \mathrm{H}-\mathrm{NMR}$ spectral data (300 MHz) for compounds 1 and 2 in $\mathrm{CD}_{3} \mathrm{OD}$.

\begin{tabular}{lcc}
\hline No. & 1 & 2 \\
\hline 1 & $7.37(\mathrm{~d}, J=16 \mathrm{~Hz})$ & $6.33(\mathrm{~d}, J=12 \mathrm{~Hz})$ \\
2 & $6.39(\mathrm{~d}, J=16 \mathrm{~Hz})$ & $5.94(\mathrm{~d}, J=12 \mathrm{~Hz})$ \\
$2^{\prime}, 6^{\prime}$ & $7.46(\mathrm{~d}, J=8.4 \mathrm{~Hz})$ & $7.53(\mathrm{~d}, J=8.8 \mathrm{~Hz})$ \\
$3^{\prime}, 5$ & $7.08(\mathrm{~d}, J=8.4 \mathrm{~Hz})$ & $7.01(\mathrm{~d}, J=8.8 \mathrm{~Hz})$ \\
$1^{\prime \prime}$ & $4.93(\mathrm{~d}, J=7.1 \mathrm{~Hz})$ & $4.88^{*}$ \\
$2^{\prime \prime-5 "}$ & $3.41-3.53(\mathrm{~m})$ & $3.40-3.46(\mathrm{~m})$ \\
$6 "$ & $3.70(\mathrm{dd}, J=4.8,13.6 \mathrm{~Hz})$ & $3.69(\mathrm{dd}, J=4.6,11.9 \mathrm{~Hz})$ \\
\hline
\end{tabular}

* Signal partially obscured by water signal. 
(90 mg) were subjected to PTLC using EtOAc/ MeOH/ $\mathrm{H}_{2} \mathrm{O}(30: 5: 4)$ as developing system to afford $50 \mathrm{mg}$ of 3 after crystallization from $\mathrm{MeOH}$.

Fractions 14 and $15(0.3 \mathrm{~g})$, eluted with $15 \% \mathrm{MeOH}$ in EtOAc, were refractionated over a flash column $(2 \mathrm{~cm}$ in diameter, $20 \mathrm{~g}$ silica gel) eluted with $12 \% \mathrm{MeOH}$ in $\mathrm{CHCl}_{3}$. Fractions 6-9 (81 mg) were rechromatographed using PTLC silica gel plates and EtOAc- $\mathrm{MeOH}-\mathrm{H}_{2} \mathrm{O}(30: 5: 4)$ as developing system (double development). Two bands were visualized under UV light, scraped off and eluted from silica with EtOAc- MeOH (1:1). After evaporation of the solvents, the first band $\left(\mathrm{R}_{f}\right.$ value $\left.=0.55\right)$ afforded $19 \mathrm{mg}$ of 1 while the second band $\left(R_{f}\right.$ value $\left.=0.47\right)$ afforded $5 \mathrm{mg}$ of 2 .

trans-Vaginoside [1- $\beta$-D-glucopyranosyl-2-(4'-hydroxyphenyl) (E) - ethene] (1)

Yellowish gum. $[\alpha]^{26} \mathrm{D}+24^{\circ}(c 0.71, \mathrm{MeOH})$. UV (MeOH) $\lambda_{\max }$ nm: 263, 204, (NaOMe) 275, 212. FABMS m/z (rel. int.): 299 (100, $\left.\mathrm{M}^{+}+\mathrm{H}\right), 279\left(9, \mathrm{M}^{+}-\mathrm{H}\right), 291$ (7), 289 (12). ${ }^{1} \mathrm{H}-\mathrm{NMR}$ : Table 1. ${ }^{13} \mathrm{C}-\mathrm{NMR}\left(\mathrm{D}_{2} \mathrm{O}\right): 61.5$ (C-6"), 70.4 (C-4"), 73.9 (C-2"), 76.5 (C-5"), 77.1 (C-3"), 100.8 (C-1"), 117.7 (C-3', C-5'), 130.4 (C-2', C-6'), 131.0 (C-2), 136.1 (C-1'), 141.9 (C-1), 158.5 (C-4').

cis-Vaginoside [1-ß-D-glucopyranosyl-2-(4'-hydroxyphenyl) (Z) - ethene] (2)

Yellowish gum. $[\alpha]^{26}{ }_{\mathrm{D}}+18^{\circ}$ (c $\left.0.52, \mathrm{MeOH}\right)$. UV (MeOH) $\lambda_{\max }$ nm: 264, 206, (NaOMe) 277, 215. FABMS m/z (rel. int.): $299\left(100, \mathrm{M}^{+}+\mathrm{H}\right), 279\left(6, \mathrm{M}^{+}-\mathrm{H}\right), 291$ (3), 289 (5). ${ }^{1} \mathrm{H}-\mathrm{NMR}$ : Table 1.

Acid hydrolysis of 1 and 2

Compound 1 (9 mg) and compound 2 (3 mg) were dissolved in $0.5 \mathrm{~mL} \mathrm{MeOH}$ and $1 \mathrm{~mL}$ of $0.1 \mathrm{~N} \mathrm{HCl}$ was added to each solution. After heating at reflux for $3 \mathrm{~h}$. the solutions were extracted with $\mathrm{CHCl}_{3}(3 \times 5 \mathrm{~mL})$. The residue left after the evaporation of solvents proved to be identical. The aqueous layer afforded 3 and $0.9 \mathrm{mg}$ of $\beta$-D-glucose, while the organic layer afforded $4 \mathrm{mg}$ and $1 \mathrm{mg}$ of (4-hydroxy-phenyl)acetaldehyde in case of $\mathbf{1}$ and $\mathbf{2}$ respectively.

\section{(4-hydroxy-phenyl)-acetaldehyde}

Yellowish oil. ${ }^{1} \mathrm{H}-\mathrm{NMR}\left(\mathrm{CDCl}_{3}\right): 3.61(2 \mathrm{H}, \mathrm{d}, J=2.3$ $\mathrm{Hz}, \mathrm{H}-2), 6.77$ (2H, d, $J=8.9 \mathrm{~Hz}, \mathrm{H}-3$ ', 5'), 7.11 (2H, d, $J$ $=8.9 \mathrm{~Hz}, \mathrm{H}-2$ ', 6'), $9.73(1 \mathrm{H}, \mathrm{t}, J=2.3 \mathrm{~Hz}, \mathrm{H}-1)$.

Hemipholin [(+) -6-C- $\beta-D-$ glucopyranosyl (2S) naringenin] (3)

Yellow crystals m.p. $208-209^{\circ} \mathrm{C}$. UV (MeOH) $\lambda_{\max } \mathrm{nm}$ : 329(sh), 288, 223, (NaOMe) 327, 243, $\left(\mathrm{AlCl}_{3}\right) 379,309,224$, $\left(\mathrm{AlCl}_{3 / \mathrm{HCl}}\right) 379,310,224,(\mathrm{NaOAc}) 327,241 . \mathrm{CD}(\mathrm{MeOH})$ : $[\theta]_{211} 0,[\theta]_{223}+16926,[\theta]_{252} 0,[\theta]_{262}-3906,[\theta]_{292}-11284$, $[\theta]_{303} 0,[\theta]_{319}+14765,[\theta]_{331} 0,[\theta]_{343}-12152,[\theta]_{365} 0$, .
Electrospray MS m/z (rel. int.): $457\left(27, \mathrm{M}^{+}+\mathrm{Na}\right), 435$ (66, $\left.\mathrm{M}^{+}+\mathrm{H}\right), 391$ (28), 276 (16), 214 (50), 163 (34), 124 (100). ${ }^{1} \mathrm{H}-\mathrm{NMR}$ (CD $\left.3 \mathrm{OD}\right): 2.73$ (dd, $\left.J=3,17 \mathrm{~Hz}, \mathrm{H}-3\right), 3.12$ (dd, $J$ $=13,17 \mathrm{~Hz}, \mathrm{H}-3), 3.34-3.44$ ( $m, \mathrm{H}-3 "-\mathrm{H}-5 "), 3.67$ (dd, $J=3$, 13 Hz, H-6"), 3.85 (dd, $J=5,12$ Hz, H-6"), 4.11 ( $m$, H-2"), 5.34 (dd, $J=3,13 \mathrm{~Hz}, \mathrm{H}-2), 5.95(s, \mathrm{H}-8), 6.79$ (d, $J=8.6 \mathrm{~Hz}$, H-3', H-5'), 7.29 (d, J = 8.6 Hz, H-2', H-6'). ${ }^{13} \mathrm{C}-\mathrm{NMR}$ (CD 3 OD): 43.9 (C-3), 62.9 (C-6"), 71.8 (C-4"), 72.6 (C-2"), 75.2 (C-1"), 80.2 (C-3"), 80.4 (C-2), 82.5 (C-5"), 96.4 (C-8), 103.2 (C-10), 106.0 (C-6), 116.3 (C-3', 5'), 129.1 (C-2', 6'), 130.9 (C-1'), 159.0 (C-4'), 163.2 (C-9),164.2 (C-5), 167.4 (C-7), 198.0 (C-4).

\section{Acknowledgments}

This work was supported in part by the University of Alexandria. The author is very grateful to Dr. Tommaso A. Foderaro for carrying out the CD spectrum of compound 3 .

\section{References}

1. Muschler, R. In A Manual Flora of Egypt; Friedlaender Shon, Karlstrasse, Berlin 1912, II, 476.

2. Tackholm, V. In Students Flora of Egypt; Cairo University, 2 nd. Ed., 1974, p 229.

3. Boulos, L. In Medicinal Plants in North Africa; Reference Publications, Inc. 1983, p 126.

4. Barrero, A.F.; Cabrera, E.; Rodriguez, I.; FernandezGallego, E.V. Phytochemistry 1994, 39, 189.

5. Tsuge, N; Mizokami, M.; Imai, S.; Shimazu, A.; Seto, H. J. Antibiot. 1992, 45, 886.

6. Scannell, R.T.; Barr, J.R.; Murty, V.S.; Reddy, K.S.; Hecht S.M. J. Am. Chem. Soc. 1988, 110, 3650.

7.Amer, M.E.; Abdel-Kader, M.S.; Mahmoud, Z.F.; Abdel-Salam, N.A.; Yang, S.S.; Mabry, T.J. Rev. Latinoamer. Quim. 1989, 20, 152.

8. Kupchan, S.M.; Sigel, C.W.; Hemingway, R.J.; Knox, J.R., Udayamurthy, M.S. Tetrahedron 1969, 25, 1603.

9. Abdel-Kader, M.S. M. S. Thesis 1989, Aexandria University.

10. Silverstein, R.M.; Bassler, G.C.; Morril, T.C. In Spectrometric Identification of Organic Compounds; John Wiley \& Sons, Inc. Fifth Ed., 1991, p 221.

11. Pouchert, C.J.; Behnke, J. The Aldrich Library of ${ }^{13} C$ and ${ }^{1}$ H FTNMR Spectra; Aldrich Chemical Company, Inc., 1993, Ed. I.

12. Padwa, A.; Wisnieff, T.J.; Walsh, E.J. J. Org. Chem. 1989, 54, 299.

13. Budzianowski, J.; Skrzypczakowa, L. Phytochemistry 1978, 17, 2044.

14. Lorente, F.T.; Ferreres, F.; Barberan, F.A.T. Phytochemistry 1982, 21, 1461.

15. Tahara, S.; Ingham, J.L.; Nakahara, S.; Mizutani, J.; Harborne, J.B. Phytochemistry 1984, 23, 1889.

16. Okamura, N.; Yagi, A.; Nishioka, I. Chem. Pharm. Bull. 1981, 29, 3507. 